\title{
KONTRIBUSI PENDAPATAN USAHATANI PADI SAWAH, ITIK PETELUR, DAN IKAN AIR TAWAR TERHADAP PENDAPATAN TOTAL USAHATANI DI KABUPATEN LEBONG
}

\section{Farm Income Contribution of Paddy Sawah, Laying duck and Fresh water fish to Total Farm Income in Lebong District}

\author{
${ }^{1}$ Satria Ageng Prasetyo, ${ }^{2} \mathrm{M}$. Mustopa Romdhon, ${ }^{2}$ Redy Badrudin \\ ${ }^{1}$ Alumni dan ${ }^{2}$ Dosen Program Studi Agribisnis, Fakultas Pertanian, \\ Universitas Bengkulu \\ ABSTRACT
}

\begin{abstract}
The paddy farming system in Amen village has experienced multicropping system among paddy, laying duck and fish. This system has economic implication to increasing faming total income. This research aims to analyze the income contribution of each farm commodity on total farm income in village Garut, Amen Subregency, Lebong regency. The method of analysis income contribution was non-cash contribution. The result showed that the contribution of each business was paddy 46 percent, duck cultivation 30 percent, and fishery 24 percent of total farm income.
\end{abstract}

Key words : Contribution, income, fish, paddy, laying duck

\section{PENDAHULUAN}

Karakteristik petani padi sawah di Kabupaten Lebong secara umum lebih difokuskan pada pada umur, matapencaharian utama, tingkat pendidikan dan lama pendidikan. Mata pencaharian utama masyarakat di Kabupaten Lebong sebagai petani padi sawah sebesar 97,5 persen. Usahatani padi sawah berkontribusi besar dalam pendapatan rumah tangga petani. Sebagian besar petani berada pada kelompok usia produktif sebesar 87,5 persen. Usia produktif berada pada kisaran 15 - 65 tahun (Mubyarto, 1980). Dalam rentang usia ini kemampuan fisik petani dalam kondisi prima untuk aktifitas usahatani padi sawah yang membutuhkan daya tahan fisik tinggi. Tingkat produktifitas kerja petani dalam rentang usia ini lebih tinggi dibandingkan rentang usia lainnya.

Rata-rata tingkat pendidikan Sekolah Dasar sebesar 47,5 persen serta Sekolah Menengah Atas sebesar 37,5 persen. Kondisi mengindikasikan bahwa pengalaman atau keahlian menjadi petani padi sawah tidak diperoleh pada pendidikan formal. Pengalaman menjadi petani padi sawah diperoleh secara turun temurun dari orang tua, tetangga atau belajar autodidak. Hal ini terindikasi dari pengalaman petani berusahatani padi sawah selama $11-20$ 
tahun. Luas lahan yang dikelola petani rata-rata 0.50 ha dengan persentase 47,5 persen. Mayoritas lahan yang dikelola sebesar 67,5 persen adalah milik sendiri.

Di musim tertentu usahatani padi sawah tidak dapat dilakukan akibat intensitas serangan hama tikus tinggi. Kondisi ini menyebabkan penurunan produksi dan pendapatan. Untuk mengatasi kondisi ini, secara turun temurun masyarakat melakukan sistem pergiliran tanaman padi-palawija, padi-ikan, padi-ikan dan itik. Hal ini secara teknis bertujuan untuk menghambat siklus alami hama tikus, sedangkan secara ekonomi untuk meningkatkan kontribusi pendapatan usahatani padi sawah. Pertanyaannya adalah seberapa besar kontribusi pendapatan tiap jenis usahatani melalui system ini terhadap pendapatan total usahatani padi sawah?

\section{METODE PENELITIAN}

Penelitian dilaksanakan pada bulan November hingga Desember 2014. Lokasi penelitian ditentukan secara sengaja yaitu di Desa Garut Kecamatan Amen Kabupaten Lebong. Responden sebanyak 40 orang ditentukan secara sensus. Kriteria responden yaitu petani membudidayakan minimal 2 komoditi yaitu padi sawah - itik petelur dan atau 3 komoditi padi sawah - itik petelur ikan air tawar.

Pendapatan dari tiap jenis usahatani dihitung dianalisis dengan formula total penerimaan dikurangi total biaya (Sukartawi, 2002).

$$
\Pi=\mathrm{TR}-\mathrm{TC}
$$

dimana $\Pi$ adalah Pendapatan cabang usaha ke i (Rp/tahun), TR adalah Penerimaan cabang usaha ke i ( $\mathrm{Rp} /$ tahun), dan TC adalah Biaya total cabang usaha ke i (Rp/tahun).

Untuk memperoleh total penerimaan adalah menggunakan rumus sebagai berikut :

$$
\mathrm{TR}=\sum \text { Pqi } \times \text { Qi }
$$

dimana $\mathrm{P}_{\mathrm{qi}}$ adalah harga produk cabang usaha ke $\mathrm{i}(\mathrm{Rp} / \mathrm{unit})$, dan $\mathrm{Q}_{\mathrm{i}}$ adalah jumlah produksi cabang usaha ke i (unit)

Kontribusi pendapatan tiap usahatani terhadap pendapatan total usahatani dihitung menggunakan persamaan (Rauaw, 2010) :

$$
\text { Kontribusi ke }-\mathrm{i}=\frac{\text { Pendapatan Usahatani ke }-\mathrm{i}(\mathrm{Rp} / \mathrm{th})}{\text { Pendapatan total Usahatani }(\mathrm{Rp} / \mathrm{th})} \times 100 \%
$$

92 | Satria Ageng Prasetyo, M. Mustopa Romdhon, Redy Badrudin, Kontribusi. 


\section{HASIL DAN PEMBAHASAN}

\section{Karakteristik Usahatani}

Sistem usahatani yang dilakukan masyarakat di Desa Garut, adalah sistem usahatani bergilir antara usahatani padi sawah, usahatani ternak itik petelur dan usahatani ikan air tawar. Usahatani padi sawah dilakukan awal tahun yaitu bulan Februari-Juni, kegiatan usahatani padi sawah dimulai dengan mengolah lahan sawah. Pengolahan lahan sawah menggunakan bbaik dengan dan menanam benih padi sawah. Penanaman padi sawah dilakukan pada bulan Maret. Benih padi sawah digunakan dibagi dua yaitu benih dibeli toko pertanian dan petani lain. Petani tidak dapat menghasilkan benih sendiri karena masa simpan yang lama sampai musim tanam berikutnya. Pupuk yang digunakan adalah pupuk anorganik serta pupuk organik dari kotoran ternak itik. Pengendalian hama dan penyakit dilakukan dengan penyemprotan pestisida untuk mencegah hama pengerek batang dan buah. Tenaga kerja terbesar adalah tenaga kerja luar keluarga. Akhir bulan Mei dan bulan Juni secara bergantian melakukan pemanenan padi, ketika padi mencapai umur tanam 100-115 hari.

Dalam satu tahun, usahatani padi sawah hanya bercocok tanam satu kali, karena pada musim tanam kedua terjadi serangan hama tikus. Populasi hama tikus mengalami peningkatan yang signifikan sehingga serangan terhadap lahan persawahan juga mengalami peningkatan dan menyebabkan kegagalan panen (Sudarmaji, 2007; Sudarmaji dan Anggara, 2008). Upaya untuk mengatasi serangan hama tikus dengan pemanfaatan lahan persawahan setelah panen padi sawah pada bulan Mei - Juli digunakan sebagai lahan budidaya itik petelur dan sebagai budidaya ikan air tawar. Metode ini juga diduga kuat mampu menjadi solusi atas rendahnya pendapatan petani padi sawah dan menekan ongkos produksi (Mantau,2011).

Lahan sewa dengan sistem bagi hasil $3: 1$ antara penggarap dan pemilik lahan. Pembayaran sewa lahan dibayar setelah panen padi sawah baik dalam bentuk gabah, beras maupun dalam bentuk uang tunai. Sistem ini umum digunakan masyarakat sebagai jaminan atas peminjaman lahan.

Peralatan penunjang usahatani padi sawah yang digunakan oleh petani sebagian besar telah melebihi umur ekonomisnya. Hal ini disebabkan orientasi petani padi sawah pada fungsi alat yang dipergunakan bukan pada umur ekonomisnya. Investasi peralatan usahatani padi sawah oleh petani sangat rendah, bahkan investasi peralatan tidak terjadi. 
ISSN: 1412-8837

Tabel 1. Kalender Usahatani Padi Sawah

\begin{tabular}{|c|c|c|c|c|c|c|c|c|}
\hline \multirow{2}{*}{ No } & \multirow{2}{*}{ Usahatani } & \multicolumn{7}{|c|}{ Bulan } \\
\hline & & 1 & 2 & 3 & 4 & 5 & 6 & 11 \\
\hline 1 & Padi & $\begin{array}{c}\text { Persiapan } \\
\text { Lahan }\end{array}$ & $\begin{array}{c}\text { Pengolahan } \\
\text { Lahan/Tanam }\end{array}$ & Tanam & Perawatan & \multicolumn{2}{|c|}{ Panen } & Serangan Hama Tikus \\
\hline 2 & Itik & Telur & \multicolumn{3}{|c|}{ Pemeliharaan Itik Tua } & Tetas & Umbar & $\begin{array}{l}\text { Pemeliharaan Itik Petelur } \\
\text { Secara Intensif }\end{array}$ \\
\hline 3 & Ikan & & Pemeliharaan In & dukan \& & Kolam Persec & liaan & & $\begin{array}{c}\text { Budidaya } \\
\text { Ikan }\end{array}$ Kemarau \\
\hline
\end{tabular}

Sumber : Data primer diolah, 2015

Mayoritas jenis itik petelur yang dibudidayakan adalah jenis itik lokal Bengkulu yaitu itik Talang Benih. Pengembangan jenis itik ini sangat dianjurkan oleh Dinas Peternakan Provinsi Bengkulu. Hal ini bertujuan untuk menjaga plasma nutfah itik lokal Bengkulu. Sistem budidaya itik dilakukan secara tradisional, dimana peliharaannya dilakukan oleh petani mulai bulan Mei dan Juni. Pengembangbiakan itik diawali dengan menetaskan telur itik. Dua metode biasa digunakan petani untuk menetaskan telur itik menjadi anakan, yaitu penetasan telur itik menggunakan ayam buras dan mesin penetasan. Selanjutnya, anakan itik dipelihara dengan sistem pengandangan dan dengan sistem dilepas pada areal persawahan hingga berumur 2 - 16 minggu. Pada system pengandangan kebutuhan pakan dipasok sepenuhnya oleh petani. Sedangkan sistem pemeliharaan dilepas pada areal sawah, kebutuhan pakan sebagian dipasok oleh petani dengan pakan buatan, sisanya itik mendapatkannya dari alam. Pakan buatan yang diberikan merupakan campuran bahan pakan seperti bekatul, padi dan pohon rumbia. Kedua sistem budidaya ini memiliki tujuan yang sama yaitu untuk menghasilkan telur itik atau itik potong. Anakan itik yang dihasilkan memiliki umur beragam untuk pembesaran, sedangkan telur itik dihasilkan dipasarkan oleh petani setiap minggu ke toko, pengumpul atau pasar. Tenaga kerja usahatani itik petelur sepenuhnya menggunakan tenaga kerja dalam keluarga terutama dalam pemberian pakan dan pemanenan telur. Biaya terbesar adalah biaya penyusutan peralatan dan kandang. Produksi telur itik berlangsung dari bulan Agustus sampai Januari. Produksi itik dipasarkan ke luar daerah seperti Kabupaten Rejang Lebong hingga ke Provinsi Sumatera Selatan.

Usahatani pembesaran ikan air tawar bersamaan budidaya itik petelur dimulai bulan Juli sampai Desember setelah musim panen padi. Pembesaran ikan bertujuan menghasilkan ikan benih ikan dan ikan konsumsi. Usahatani ikan air tawar yang dijalakan petani dengan memanfaatkan petakan sawah sebagai kolam. Pakan ikan yang digunakan adalah pakan alami sisa tanaman padi dan planton yang berasal dari kotoran itik. Masa pembesaran ikan air tawar yaitu satu sampai tiga bulan tergantung pada tujuan budidaya yaitu sebagai anakan atau sebagai ikan konsumsi. 


\section{Struktur Biaya Usahatani}

Biaya usahatani padi sawah, itik petelur dan ikan air tawar ditentukan oleh tingkat alokasi input produksi selama satu tahun, seperti disajikan pada Tabel 2. Fokus jenis biaya usahatani mencakup biaya variabel antara lain bibit, pupuk, pakan, DOD, pestisida, transportasi,dan tenaga kerja. Sedangkan biaya tetap antara lain sewa lahan, pinjaman bank dan penyusutan alat.

Struktur biaya usahatani dominan yaitu biaya tenaga kerja, biaya pupuk/pakan, bagi hasil, biaya benih/DOD, penyusutan peralatan, pestisida, sewa lahan, transportasi dan pinjaman bank. Persentase kontribusi biaya tenaga kerja lebih tinggi dibandingkan biaya lainnya secara total mencapai 45,47 persen. Biaya tenaga kerja terdiri dari tenaga kerja dalam keluarga $(22.13 \%)$ dan tenaga kerja luar keluarga (23.34\%). Sistem usahatani pergiliran menyerap banyak tenaga kerja pada kegiatan seperti pengolahan lahan, pemeliharaan dan panen. Sistem ini pada kegiatan - kegiatan tertentu juga menciptakan efisiensi penggunaan input produksi. Menurut Soekartawi, (1993), efisiensi dimaknai sebagai penghematan penggunaan input per satuan output yang dihasilkan. Hal ini karena adanya penggunaan input secara bersamaan dari ketiga usahatani tersebut misalnya pengunaan peralatan, pakan, dan penggunaan lahan.

Tabel 2. Biaya usahatani per tahun (Rp/th)

\begin{tabular}{|c|c|c|c|c|c|c|c|c|c|}
\hline \multirow{2}{*}{ No } & \multirow{2}{*}{ Jenis Biaya } & \multicolumn{6}{|c|}{ Usahatani } & \multirow{2}{*}{ Total } & \multirow{2}{*}{$\%$} \\
\hline & & Itik & $\%$ & Padi & $\%$ & Ikan & $\%$ & & \\
\hline \multirow[t]{8}{*}{1} & Variabel & & & & & & & & \\
\hline & Bibit/DOD & 325,030 & 10.04 & 100,388 & 2.18 & 568,750 & 59.32 & 994,168 & 11.30 \\
\hline & Pupuk/Pakan & $1,584,206$ & 48.91 & 562,900 & 12.24 & 99,000 & 10.33 & $2,246,106$ & 25.53 \\
\hline & Pestisida & - & - & 138,225 & 3.01 & 1,600 & 0.17 & 139,825 & 1.59 \\
\hline & Transportasi & 18,000 & 0.56 & - & - & - & - & 18,000 & 0.20 \\
\hline & T.Keluarga & $1,119,231$ & 34.56 & 624,094 & 13.57 & 202,969 & 21.17 & $1,946,294$ & 22.13 \\
\hline & T.Luar keluarga & - & - & $2,023,516$ & 44.00 & 29,688 & 3.10 & $2,053,204$ & 23.34 \\
\hline & Bagi Hasil & - & - & $1,030,500$ & 22.41 & - & - & $1,030,500$ & 11.71 \\
\hline \multirow[t]{5}{*}{2} & Tetap & & & & & & & & \\
\hline & Sewa lahan & - & - & 39,875 & 0.87 & - & - & 39,875 & 0.45 \\
\hline & Pinjaman Bank & - & - & 16,067 & 0.35 & - & - & 16,067 & 0.18 \\
\hline & $\begin{array}{l}\text { Penyusutan } \\
\text { Peralatan }\end{array}$ & 192,359 & 5.94 & 63,659 & 1.38 & 56,733 & 5.92 & 312,751 & 3.56 \\
\hline & Total & $3,238,826$ & 100 & $4,599,224$ & 100 & 958,740 & 100 & $8,796,790$ & 100 \\
\hline
\end{tabular}

Sumber : Data primer diolah, 2015

Secara individu, persentase kontribusi biaya usahatani padi sawah lebih besar dibandingkan usahatani itik dan ikan berturut-turut sebesar 57 persen, 37 persen dan 11 persen. Kontribusi biaya terbesar pada usahatani padi sawah didominasi oleh biaya tenaga kerja, bagi hasil dan pupuk. Perbedaan ini akibat 
perbedaan peran input serta karakteristik usahatani. Pada usahatani itik didominasi oleh biaya pakan, tenaga kerja dan benih. Pada usahatani ikan didominasi oleh biaya bibit, tenaga kerja dan pakan. Biaya tenaga kerja sangat penting pada ketiga jenis usahatani tersebut karena ketiga usahatani bersifat padat karya. Dari ketiga jenis biaya dengan kontribusi terbesar semua berkaitan langsung dengan produksi yaitu biaya tenaga kerja, pupuk, pakan, dan benih/bibit, kecuali biaya bagi hasil. Beberapa cara menekan biaya tenaga kerja melalui penggunaan teknologi produksi tepat guna.

\section{Struktur dan Kontribusi Pendapatan Usahatani}

Pendapatan usahatani dihitung selama satu tahun untuk ketiga jenis usahatani yaitu usahatani padi sawah, itik petelur dan ikan air tawar. Ketiga jenis usahatani memanfaatkan lahan sawah secara bergantian dimulai dari usahatani padi sawah, itik petelur dan ikan air tawar. Secara rinci pendapatan usahatani tersaji pada Tabel 3.

Pendapatan usahatani terbesar adalah pendapatan yang dimanfaatkan atau dikonsumsi oleh keluarga petani dalam pemenuhan kebutuhan keluarga berupa beras. Beras merupakan komponen utama sebagai bahan pangan yang belum dapat digantikan oleh bahan pangan lainnya. Pendapatan terbesar usahatani masih bersumber dari usahatani padi sawah. Pendapatan usahatani padi sawah hanya bersumber dari penjualan beras. Hasil penjualan beras dimanfaatkan untuk memenuhi kebutuhan biaya pendidikan serta untuk memenuhi kebutuhan harian keluarga seperti dan lauk pauk. Petani belum memanfaatkan hasil panen lain diluar beras sebagai sumber pendapatan langsung yang berasal dari usahatani padi sawah seperti penjualan dedak dan bekatul. Namun demikian hasil produksi dedak dan bekatul dikonsumsi sendiri sebagai sumber pakan ternak itik dan ikan air tawar. Dampaknya, ongkos produksi budidaya ternak menjadi berkurang.

Sumber pendapatan utama pada usahatani itik terbesar dari penjualan telur, daging itik, anakan itik umur 2 - 3 bulan serta itik afkir. Jenis produksi yang dipasarkan oleh petani ititk di Desa Garut disesuaikan permintaan pasar. Umumnya permintaan pasar lokal terbagi dua yaitu permintaan untuk konsumsi dan untuk produksi. Permintaan dalam bentuk konsumsi berupa produksi telur dan daging itik sedangkan permintaan untuk produksi dalam bentuk itik dara. Konsumen yang membutuhkan berbeda dimana penjualan telur dilakukan di sekitar desa kepada pedagang pengumpul, toko atau pasar. Sementara hasil produksi anakan itik dan itik afkir dijual kepada pedagang pengumpul dan petani padi sawah berternak itik.

Pendapatan dari ternak ikan air tawar diperoleh dari penjualan jenis ikan nila dan ikan mas. Jenis produksi ditentukan oleh permintaan pasar dalam bentuk ikan siap konsumsi dan ikan produksi (anakan ikan). Permintaan pasar sangat menentukan waktu panen oleh petani. Ikan untuk dikonsumsi langsung 
oleh konsumen rumah tangga dan rumah makan, umumnya dipanen saat berumur satu sampai tiga bulan dimana bobot ikan mencapai bobot 200 - 350 gram per ekor. Sebaliknya ikan untuk dibudidayakan kembali dipanen saat berumur kurang dari satu bulan.

\section{Tabel 3. Pendapatan Usahatani (Rp/th)}

\begin{tabular}{|c|c|c|c|c|}
\hline \multirow{2}{*}{ No } & \multirow{2}{*}{ Uraian } & \multicolumn{3}{|c|}{ Pendapatan (Rp/th) } \\
\hline & & Tunai & Non Tunai & Total \\
\hline \multirow[t]{13}{*}{$\mathrm{I}$} & Itik petelur & & & \\
\hline & a. DOD & 200,000 & - & 200,000 \\
\hline & b. Itik umur $1 \mathrm{minggu}$ & 142,500 & - & 142,500 \\
\hline & c. Itik umur 2 minggu & 114,150 & - & 114,150 \\
\hline & d. Itik umur 2 bulan & 866,475 & - & 866,475 \\
\hline & e. Itik umur 3 bulan & 250,250 & - & 250,250 \\
\hline & f. Itik umur 4 bulan & 209,375 & - & 209,375 \\
\hline & g. Itik dewasa & 52,400 & - & 52,400 \\
\hline & h. Itik afkir & 77,550 & - & 77,550 \\
\hline & i. Telur & $5,663,295$ & 91,425 & $5,754,720$ \\
\hline & Subtotal & $7,575,995$ & 91,425 & $7,667,420$ \\
\hline & Biaya & $(1,927,236)$ & $(1,311,590)$ & $(3,238,826)$ \\
\hline & Subpendapatan total & $5,648,759$ & $-1,220,165$ & $4,428,594$ \\
\hline \multirow[t]{7}{*}{ II } & Padi Sawah & & & \\
\hline & Beras & $3,888,375$ & $7,228,000$ & $11,116,375$ \\
\hline & Gabah & - & - & 0 \\
\hline & Bekatul & - & 376,160 & 376,160 \\
\hline & Subtotal & $3,888,375$ & $7,604,160$ & $11,492,535$ \\
\hline & Biaya & $(2,853595)$ & $(1,745,628)$ & $(3,568,723)$ \\
\hline & Subpendapatan total & $1,034,780$ & 5,858532 & $7,923,813$ \\
\hline \multirow[t]{9}{*}{ III } & Ikan air tawar & & & \\
\hline & Produksi pertama & $1,002,846$ & 56,615 & $1,059,461$ \\
\hline & Produksi kedua & 827,833 & 52,556 & 880,389 \\
\hline & Produksi ketiga & 808,400 & 53,600 & 862,000 \\
\hline & Produksi keempat & 917,250 & 54,000 & 971,250 \\
\hline & Produksi kelima & 645,000 & 55,000 & 700,000 \\
\hline & Subtotal & $4,201,329$ & 271,771 & $4,473,100$ \\
\hline & Biaya & $(699,038)$ & $(259,701)$ & $(923,006)$ \\
\hline & Subpendapatan total & $3,502,291$ & 12,070 & $3,550,094$ \\
\hline IV & Total & $10,185,830$ & $4,650,438$ & $14,836,268$ \\
\hline
\end{tabular}

Sumber : Data primer diolah, 2015

Pendekatan menghitung pendapatan dalam penelitian ini berdasarkan pendapatan ntunai dan pendapatan no-tunai. Pendapatan tunai artinya seluruh komponen dihitung hanya berdasarkan nilai yang sesungguhnya dikeluarkan. Pendapatan non-tunai menghitung seluruh komponen berdasarkan nilai yang 
sesungguhnya dikeluarkan maupun yang tidak dikeluarkan seperti biaya tenaga kerja dan sewa lahan.

Pendapatan diperoleh petani berdasarkan perhitungan metode tunai seperti disajikan pada Tabel 4 menunjukkan kontribusi pendapatan dari usahatani padi sawah sebesar 46 persen, itik petelur sebesar 30 persen, dan ikan sebesar 11 persen dari pendapatan total usahatani. Kontribusi pendapatan padi lebih besar dibandingkan kontribusi pendapatan usahatani itik petelur dan ikan. Sedangkan kontribusi pendapatan usahatani itik petelur lebih besar dibandingkan pendapatan ikan air tawar terhadap pendapatan total usahatani. Sedangkan pendapatan diperoleh petani berdasarkan perhitungan metode nontunai seperti disajikan pada Tabel 4 menunjukkan bahwa pendapatan usahatani padi sawah lebih besar dibandingkan pendapatan usahatani ternak itik dan kolam ikan air tawar, bahkan usahatani itik rugi sebesar 26 persen.

Temuan ini memperkuat dugaan awal bahwa pendapatan usahatani padi sawah masih menjadi sumber pendapatan utama rumah tangga petani untuk memenuhi kebutuhan hidup, sedangkan pendapatan yang bersumber dari usahatani itik petelur dan kolam ikan air tawar masih menjadi sumber pendapatan pendamping. Hasil lain seperti penelitian Ifdal (1992) menunjukkan kontribusi pendapatan dari usahatani ayam ras petelur sebesar 84,71 persen, sedangkan usahatani padi sawah hanya berkontribusi sebesar 12,64 persen dan non-usahatani berkontribusi sebesar 2,65 persen. Penelitian Nurwahyuni (2013), usahatani skala I berkontribusi sebesar 66,92 persen, skala II berkontribusi sebesar 87,68 dan skala III berkontribusi sebesar 97,12 persen. Kontribusi terbesar yaitu usahatani skala III (ayam ras petelur) sebagai usahatani utama keluarga.

Tabel 4. Kontribusi Pendapatan Usahatani Itik Petelur

\begin{tabular}{|c|c|c|c|c|c|c|c|c|}
\hline \multirow{2}{*}{ Uraian } & \multicolumn{4}{|c|}{ Pendapatan (Rp) } & \multicolumn{3}{|c|}{ Kontribusi (\%) } & \multirow{2}{*}{$\begin{array}{r}\text { Tota } \\
(\%)\end{array}$} \\
\hline & Itik & Padi & Ikan & Total & Itik & Padi & ikan & \\
\hline Tunai & $5,648,759$ & $1,034,780$ & $3,502,291$ & $10,185,830$ & 55 & 10 & 34 & 100 \\
\hline Non Tunai & $-1,220,165$ & $5,858,533$ & 12,070 & $4,650,438$ & -26 & 126 & 0,26 & 100 \\
\hline Total & $4,428,594$ & $6,893,313$ & $3,514,361$ & $14,836,268$ & 30 & 46 & 24 & 100 \\
\hline
\end{tabular}

Sumber : Data primer diolah, 2015

Implikasi dari penelitian ini adalah program pengembangan usahatani berbasis multi usahatani padi sawah, itik dan ikan kolam air tawarseperti dilakukan masyarakat Desa Garut penting untuk meningkatkan pendapatan petani padi sawah. Hal ini didukung oleh karakteristik daerah hanya bisa bercocok tanam satu kali setahun. Program ini dapat dilakukan secara padat karya maupun padat teknologi. Program ini dibarengi dengan bantuan modal 
usahatani terutama modal produksi khususnya bagi 32 persen petani penggarap dan petani padi sawah umumnya.

\section{SIMPULAN}

Hasil penelitian menunjukkan kontribusi terbesar pendapatan usahatani yang diperoleh petani berturut-turut adalah padi sawah sebesar 46 persen, itik petelur sebesar 30 persen, dan ikan sebesar 24 persen dari pendapatan total usahatani. Kontribusi pendapatan padi sawah lebih besar dibandingkan kontribusi pendapatan usahatani itik petelur dan ikan. Pendapatan usahatani padi sawah masih menjadi sumber pendapatan utama rumah tangga petani padi sawah untuk memenuhi kebutuhan hidup, sedangkan pendapatan yang bersumber dari usahatani itik petelur dan kolam ikan air tawar menjadi sumber pendapatan pendamping. Oleh karena itu, pengembangan usahatani berbasis multi usahatani seperti usahatani padi sawah - itik dan ikan dapat dijadikan salah satu cara meningkatkan pendapatan petani padi sawah.

\section{DAFTAR PUSTAKA}

Ifdal. 1992. Kontribusi pendapatan usahatani ternak ayam ras petelur dalam pendapatan keluarga petani di perwakilan kecamatan Guguk kabupaten 50 Kota. Fakultas pertanian, Universitas Andalas. Padang.

Mantau, Zulkifli. 2011. Usahatani Terpadu Padi, Ikan, Itik. http://epetani.pertanian.go.id/budidaya/usahatani-terpadu-padi-ikan-itik1867.

Marimin. 2005. Teknik dan Aplikasi pengambilan keputusan kriteria majemuk. Grasindo. Jakarta.

Mubyarto. 1980. Ilmu Ekonomi, Ilmu Sosial dan Keadilan. Yogyakarta: UGM Press.

Nurwahyuni, Eka, dkk. 2013. Faktor-faktor yang mempengaruhi kontribusi usahatani ternak ayam ras petelur terhadap pendapatan rumah tangga di Kecamatan Kras Kabupaten Kediri. Fakultas Peternakan Universitas Brawijaya. Malang.

Rauaw, Eyverson dkk. 2010. Kontribusi usahatani kelapa terhadap pendapatan keluarga petani di Desa Naha dan Desa Beha Kecamatan Tabukan Utara 
ISSN: 1412-8837

Kabupaten Kepulauan Sangihe. Ase - Volume 6 Nomor 3, September 2010: 16-25.

Soekartawi 1993 1993.Prinsip Dasar Ekonomi Pertanian - Teori dan Aplikasi, PT.Raja Grafindo, Jakarta.

Soekartawi. 2002. Analisis usahatani. UI Prees, Jakarta.

Sudarmaji. 2007. Struktur Umur Populasi Tikus Sawah pada Berbagai Stadium Tanaman Padi. Balai Besar Penelitian Tanaman Padi. Subang.

Sudarmaji dan Anggara Wahyana Anggara. 2008. Perkembangan Populasi Tikus Sawah (Rattus argentiventer) dan Pengaruhnya terhadap Tingkat Kerusakan Tanaman Padi. Seminar Nasional Padi. Balai Besar Penelitian Tanaman Padi. Subang.

100 | Satria Ageng Prasetyo, M. Mustopa Romdhon, Redy Badrudin, Kontribusi. 